\title{
VERSIONS AND INVERSIONS of PETRONIUS' SATYRICON IN The Great Gatsby
}

\section{Silvia Mara Tellini*}

\begin{abstract}
Considering Bakhtin's concept of carnavalization, this analysis explores comparatively Petronius's The Satyricon and Fitzgerald's The Great Gatsby, aiming at a discussion of the intertextuality established between the protagonists Trimalchio and Gatsby, as well as the tight relations that emerge from the positions of both narrators, Encolpio and Nick Carraway. Furthermore, in order to accomplish that, the essay refers back to the film adaptations of Fitzgerald's novel, directed by Jack Clayton (1974), as well as the more recent one by Bax Luhrmann (2013).
\end{abstract}

Keywords: Satyricon. The Great Gatsby. Carnavalization.

$\boldsymbol{A}$ ccording to Mikhail Bakhtin, the tragic-comic genre has always been present in the history of literature. Petronius' Satyricon is an example of the Menippean satire and it is considered one of the founding texts of the carnival tradition in the West, alongside Socratic dialogues where the logical stands as illogical. In Rabelais and his world and Problems of Dostoevsky's Poetics, Bakhtin highlights the carnavalization of Petronius' literature in a continuously changing society as he exemplifies his concept by pointing to the plot, describing how the contrasts in the character's ambiguous logic surfaces while the reader is shown the underground world of the decadent Nero governing period, around I AD. Multiple voices emerge insofar as Petronius surrenders his authorial control by composing parodies of classical poets as well as by depicting absurdly comical and grotesque characters.

The comical contrasts are not only synchronically generated throughout the various dialogues with his contemporaries, but are also established diachronically through dialogue with classical poets that preceded Petronius. In other words, 
Satyricon is a "disenchanted portrayal of a changing contemporary society, with its use of laughter meant to defamiliarize approved ideologies and ideas and its roots in folklore and festive rituals" (BEVILACQUA, 2004, p. 111). The narrative is also innovative, since it is the first, that we know of, presenting interfaces between prose and poetry. Moreover, Petronius was the first to introduce a first person narrator.

Along these lines, Fitzgerald also creates in The Great Gatsby (1971) a narrative portraying the morally decadent society of the prosperous post war period in the twenties, the Jazz Era in the United States, which includes straightforward references to The Satyricon. Indeed, the first draft of Fitzgerald's novel was entitled Trimalchio, referring back to the character in the longest recovered scene of the Satyricon, Dinner with Trimachio. Fitzgerald establishes a dialogue between Gatsby and Trimalchio, creating another nouveau riche, who spends his time throwing exuberant parties attended by people from different social classes. Beyond that, both first person narrators, Nick Carraway and Encolpios, also present contact areas in terms of positioning themselves as being schooled and able to present a privileged view of their own societies.

The aim here is to focalize some of the relations between two protagonists, as well as between the narrators from both works, exploring their dialogical interaction through proximities, distancing and parodical referring. Indeed, Trimalchio can be considered a protagonist since his dinner scene is the longest and less fragmented chapter recovered.

The plot of The Great Gatsby opens up with Nick moving from the Middle West to Long Island to spend time studying the booming financial market. He introduces himself as young man coming from an educated and wealthy background, as he states:

In my younger and more vulnerable years my father gave me some advice that I've been turning over in my mind ever since. "Whenever you feel like criticizing any one", he told me, "just remember that all the people in this world haven't had the advantages that you've had" (FITZGERALD, 1971, p. 4).

Nick perceives his contemporary young men as only being capable of uncreative and distorted expressions of themselves, furnishing the ideology of his morally decadent era, a time when crime rates rocketed as a result of illegal activities connected to the blooming bootleg liquor commerce.

Similarly, the first fragment of The Satyricon presents Encolpios as a student, therefore a citizen of an upper social class, who believes his contemporary students have been made stupid by school, inasmuch as they do not learn to truly understand the speeches, and end up disfiguring their discourse by diverting their attention to the frivolous playing on words and sounds. The passages below illustrate the parallel between both narrators:

[...] in college I was unjustly accused of being a politician, because I was privy to the secret griefs of wild, unknown men. Most of the confidences were unsought - frequently I have feigned sleep, preoccupation, or a hostile levity when I realized by some unmistakable sign that an intimate revelation was quivering on the horizon; for the intimate revelations of young men, or at least the 
terms in which they express them, are usually plagiaristic and marred by obvious suppressions (FITZGERALD, 1971, p. 4).

[...] but as it is, their sole gain from this ferment of matter and empty discord of words is, that when they step into the Forum, they think they have been carried into another world. And it is my conviction that the schools are responsible for the gross foolishness of our Young men, because, in them, they see or hear nothing at all of the affairs of everyday life, but only pirates standing in chains upon the shore, tyrants scribbling edicts. [...] With your well-modulated and empty tones you have so labored for rhetorical effect that the body of your speech has lost its vigor and died (PETRONIUS, 1943, p. 41-2).

Both Nick and Encolpios begin their narrative setting themselves apart from their contemporary frivolous and inauthentic society. However, as both narratives unfold, they cannot refrain from becoming active participants in the adventures narrated. Encolpios, although belonging to the Roman society, prefers to live like a beggar student, going from one place to the other, as he joins in straightforward sexual games. Whilst he lacks ambition, Nick pursues the studies of the financial market, perhaps to carry on working at Wall Street, one of the symbols of the American ambition. Nevertheless, he also attends a series of parties at Gatsby's, a character who had initially been perceived as someone who represented "everything Nick had an unaffected scorn" (FITZGERALD, 1971, p. 5).

Conversely to Nick's changing of perspectives, according to Niall W. Slater (130) Encolpios delivers a satiric but static view of Trimalchio. Nick goes from feeling scorn to empathizing with Gatsby along the narrative. The turnaround happens during the revelation of the millionaire's poor background as a consequence of Tom Buchanan's interrogation after the car accident, when Daisy drives over Myrtle, Tom's mistress, but everyone believes it was Gatsby who was driving the car.

In the earlier version of the book, Trimalchio, Fitzgerald had actually written Gatsby's lines disclosing his poor background as an epiphany when he tells Nick:

"You know, old sport, I haven't got anything", [...] "I thought for a while I had a lot of things, but the truth is that I'm empty, and I guess people feel it. That must be why they keep making up things about me, so I won't be so empty. I even make up things about myself". He looked at me frankly. "I'm not an Oxford man" (FITZGERALD, 1971, p. 116).

The more Nick knows about Gatsby's background, the more he changes his view of him, to the point of now seeing him as a unique man, possessing qualities that made him "gorgeous", as he describes: "it was an extraordinary gift for hope, a romantic readiness such as I have never found in any other person and which it is not likely I shall ever find again. No - Gatsby turned out all right at the end" (FITZGERALD, 1971, p. 5). The first pages announce Nick's reflections on what Gatsby has become to him in the end, standing out as an outsider, as he asserts in the passage below:

When I came back from the East last autumn I felt that I wanted the world to be in uniform and at a sort of moral attention forever; I wanted no more riotous 
excursions with privileged glimpses into the human heart. Only Gatsby, the man who gives his name to this book, was exempt from my reaction (FITZGERALD, 1971, p. 5).

As his point of view changes gradually, Gatsby's image is transformed from one of a tacky nouveau riche, portrayed in a flamboyant manner, with nuances similar to those of Trimalchio's excessive corny character, into becoming, ultimately, the reflection of a man of character and value, who does not betray his love and friends, while keeping his hope and pursuing grand plans.

Some critics claim that the relationship Nick develops with Gatsby depicts homoerotic nuances. That may bear comparative associations with Encolpios' explicit homoerotic relationship with Giton and Ascyltos; nevertheless Nick's motivations are far from coinciding with the gaiety and obscenity in Satyricon. Nick further expresses feelings of admirations and comes to respect Gatsby along the novel, whereas Encolpios has no respect for himself and even less for his partners.

In one of the passages, Encolpios enters a dispute with Ascyltos over Giton, during which they discuss whether they should divide the boy in two halves (PETRONIUS, 1947, p. 147-149). Encolpios wakes up in the middle of the night and does not find Giton, who is sleeping beside Ascyltos. Encolpios demands him to leave after they divide their spoils, including Giton. The dispute over Giton is considered by many scholars a parody of the dispute between Achilles and Agamemnon over Briseis in the Iliad. Achilles had captured her, but Agamemnon took her in exchange of Chryseis being returned to her father (DOULAMIS, 2011, p. 80). Petronius creates a scene where the three boys reenact the dispute, however with a comic element present in their desire to divide Giton in two. The problem is that Encolpios is certain that Giton would prefer to be by his side and has an idea to resolve the situation as he precipitately proposes that the dispute should be "submitted to the judge" (PETRONIUS, 1947, p. 149), however he is caught with his pants down as Giton "got up and chose Ascyltos as soon as the last syllable had passed my lips". Moreover, the comedy in the scene also stems from the complete lack of consideration and loyalty amongst the three of them.

Fitzgerald also creates a triangle involving Nick's sentimental feelings for Gatsby and the golf player, Jordan Baker. However the nature of their relation in Fitzgerald novel is far more veiled, making it difficult to claim any certainty on what the characters feel since the narrator himself changes his views of the other characters.

Opposed to the three petty students, who have their actions openly described with all their intentions made explicit, Nick narrates his admiration for Gatsby, constructing ambiguous layers of feelings which cannot be categorized under the determined spectrum of what romantic, friendly or passionate means. On the other hand, Nick makes it also difficult for the reader to understand the nature of his involvement with Jordan Baker as he describes their meetings at Gatsby's parties, car rides and tea times together. When he first meets her, he says he likes to look at that "slender, small breasted girl, with an erect carriage, which she accentuated by throwing her body backward at the shoulders like a young cadet" (FITZGERALD, 1971, p. 11). The descriptions of her physicality reinforce the ambiguity of the gender, as she lacks what in hindsight has been constructed traditionally as the representation of the femaleness of the curvaceous body, thus comparing her to a cadet. Regardless 
whether the author created Jordan as a parody of Ascyltos intentionally or not, the fact that the plot drives Nick to spend moments alone with only both the player and Gatsby is relevant once it leads the readership on to accessing the millionaire and Jordan in more intimate moments with the narrator.

Furthermore, Gatsby is also immersed in a confusion of symbols and the platonic love for Daisy, which enhances the ambiguity and complexity of the ironic intertextuality and parodies. Consequently, as the reader learns about Gatsby's past in extreme poverty, the parodical elements in relation to Trimalchio's story escalate to different dimensions.

Jay Gatz of North Dakota is a self-made man who found a patron when he was seventeen, intending to leave his fortune to Gatsby. Likewise, Trimalchio is a freedman who inherited the fortune of his master. However, if Trimalchio inherited the money, Gatsby only inherits the good manners of a gentleman by whom he had been trained. Despite losing his master's inheritance, Gatsby becomes this wealthy man commanding illegal liquor trading in several States.

Both characters try to ensure their images are conveyed through their exhibition of wealth. One way to do that is through their extravagant houses, or rather, palaces, displaying all sorts of lavishing elements as we can verify in the passages below:

If I can extend my boundaries so as to join Apulia, I'll think I've amounted to something in this life! I built this house with Mercury on the job, anyhow; it's a palace now! Four dining rooms, twenty bedrooms, two marble colonnades, a store-room upstairs, a bedroom where I sleep myself, a sitting room for this viper, a very good room for the porter, a guest-chamber for visitors (PETRONIUS, 1947, p. 145).

With enchanting murmurs Daisy admired this aspect or that of the feudal silhouette against the sky, admired the gardens, [...] It was strange to reach the marble steps and find no stir of bright dresses in and out the door [...]

And inside, as we wandered through Marie Antoinette music rooms and Restoration salons, I felt that there were guests concealed behind every couch and table [...]

As Gatsby closed the door of "the Merton College Library" [...]

We went up-stairs, through period bedrooms swathed in rose and lavender silk and vivid with new flowers, through dressing rooms and poolrooms, and bathrooms (FITZGERALD, 1971, p. 70)

The descriptions tightly relate both their dwellings. Regarding particularly the library, both Trimalchio and Gatsby refer to their huge libraries as a symbol of their supposed high education. Trimalchio claims "I studied literature for home use, for fear you should think I don't care about learning, let me inform you that I have three libraries, one Greek, and the others Latin" (p. 105-106), whilst Gatsby has a "high Gothic library, paneled with carved English oak, and probably transported complete from some ruin overseas" (p. 36).

However, unlike Gatsby, who has been trained in the manners of a gentleman and is able to disguise his real social background, Trimalchio provokes laughter amongst his guests while making the most absurd confusions between historical 
facts, which he claims to have learned from his libraries. Moreover, the fact that Fitzgerald describes Gatsby's library as being transported from an ancient place located in another continent may be a parody to Trimalchio's library, as if one was inheriting the empty appearances and lack of formal education from the other.

The exaggerated obsession of the characters with displaying their wealth goes beyond their possessions, insofar as they also create extravagant parties and personas. Nevertheless, Trimalchio is portrayed as a very rude and distasteful man, whereas Gatsby is perceived as a good-looking and charming man, despite also possessing corny features. Trimalchio's and Gatsby's features are narrated in the passages below:

All of sudden we caught sight of an old fellow, rugged out in a russet-colored tunic [...] playing with a green ball. [...] Timalchio snapped his fingers; the eunuch, hearing the signal, held the pot for him while he still continued playing. After reliving himself he called for water to wash his hands, barely moistened his fingers, and dried them upon a boy's head (PETRONIUS, 1947, p. 79-80).

it was an extraordinary gift for hope, a romantic readiness such as I have never found in any other person and which it is not likely I shall ever find again. No - Gatsby turned out all right at the end (FITZGERALD, 1971, p. 5)

His tanned skin was drawn attractively tight on his face and his short hair looked as though it were trimmed every day. [...] Well, he told me once he was an Oxford man." [...] "However, I don't believe it (FITZGERALD, 1971, p. 40).

Gatsby is perceived by the narrator as a smart man on the surface; nevertheless, the manner in which he attempts to display his education lacks a genuine flair, inasmuch as he chooses pompous words and gestures, a fake manner which is detected by the traditional old riches, such as Tom (p. 94) and Jordan (p. 40). Tom claims: "An Oxford man!" He was incredulous. "Like hell he is! He wears a pink suit” (p. 40).

Whereas Gatsby tends to like a corny lifestyle, Trimalchio escalates his bad taste to the point of explicit humor that cannot be contained with appearances at all. When he attempts to display he is a well-read man, he hilariously misinterprets different historical periods, joining characters that could never have lived in the same historical era, as he brags about in the next passage:

Diomedes and Ganymede were two brothers, and Helen was their sister Iphigenia, to Achilles, for a wife: this palmed off a doe on Diana, in her place, so Homer tells how the Trojans and Parentines fought among themselves. Of course Agamemnon was victorious and gave his daughter Iphigenia, to Achilles for a wife. This caused Ajax to go mad (p. 120).

According to Martin S. Smiths (KÖNIG; WHITMARSH, 2007, p. 123), Petronius articulates a dense comedy out of Trimalchio's absurd ignorance of history and mythology, as he distorts events in the wild story above. He replaces Castor and Pollux with the Greek warrior Diomedes and the Trojan boy Ganymedes only on account of their similar names. He also replaces Paris with Agamemnon as Helen's 
abductor, and in his version Helen is crossed with Iphigenia who actually marries Achilles at the end of the war. Ajax, instead of being in rage because the arms of dead Achilles were then given to Ulysses, becomes jealous instead, as he is more concerned with Achilles' marriage to Iphigenia.

The most grotesque elements are featured at Trimalchio's feast, as he is having dinner served whilst commenting on his flatulence condition. On the other hand, the grandiose absurdity is featured when he mentions his lands and makes the size of them sound vaster than it would be possible in reality as he explains: "my country places which I've never yet seen, but they tell me it's down Terracina and Tarentum way. 'I've got a notion to add Sicily to my other little holdings" (p. 105).

Trimalchio sees himself as such an important person that he pretends to be at his own funeral in order to hear the elegiac speeches in his honor. Moreover, his house is portrayed as having a very distasteful objects jammed out of place and spread all over his palace. The mingling of different social classes is reflected in his guest list. Besides the students who show up at his dinner, his guests include the rhetorician Agamemnon, Phileros, a lawyer and former travelling salesman, Habinnas, a stonemason, Echion, who works in the rag trade, Proculus, an undertaker, Diogenes, another self-made businessman, Scintilla (Habinas' wife) and Fortunata, his own wife.

Gatsby's mansion and parties are also extravagant. According to Bevilacqua (2004, p. 113), Gatsby's parties

[...] fuses carnivalesque elements from folkloric and literary traditions such as the feast and the grotesque body with the specific features of his own time and place, and makes a profoundly significant use of symbolic inversions as the defining image of climactic moments in his narrative.

From that perspective, the parties acquire a time flow out of the natural progression of historical temporality. Nick writes down the names of the guests attending the parties; they come from East Egg (where the old riches live) as well as from West Egg (where the new riches live) and are named under historical figures or representing different ethnical origins, or even under ironic animal or vegetable names, as we can read in the passage below:

From East Egg, then, came the Chester Beckers and the Leeches, and a man named Bunsen, whom I knew at Yale, and Doctor Webster Civet, who was drowned last summer up in Maine.[...] And the Hornbeams and the Willie Voltaires, And the Ismays and the Chrysties (or rather Hubert Auerbach and Mr. Chrystie's wife), and Edgar Beaver, Clarence Endive was from East Egg, [...] From farther out on the Island came the Cheadles and the O. R. P. Schraeders, and the Stonewall Jackson Abrams of Georgia, [...] From West Egg came the Poles and the Mulreadys [...] Da Fontano the promoter came there, and Ed Legros and James B. ("Rot-Gut.") (p. 47-48).

He goes on for pages naming this heterogeneous crowd described as Gatsby parties' guests, which offers an image of the new American society growing in the 1920s, whilst challenging the existing hierarchy as well as the corrupted current morality by strengthening the bond between legal and illegal activities. At the 
parties, the rules of society do not apply as the guests enjoy all the eating and drinking while a kaleidoscope of different music and dancing encourages the Dionysian excess that liberates them from the current order, or at least, as Nick seems to realize later, creates a mirage of liberation which is not real.

It is in this disordered scenario where people meet not as a cohesive group, but rather as strangers who cannot bond beyond that, but share a time without perspectives and outside the rules of capitalist society, similarly to the how Satyricon's three scoundrel students live. Likewise, Fitzgerald portrays the upper class as an empty free flowing group that is not tied down to any moral or group. Jordan, for instance, states that she likes large parties because "they're so intimate. At small parties, there isn't any privacy (40)", inverting the logic of what the possibility of meeting people beyond superficialities would signify. Large parties, where she finds herself surrounded by strangers and disconnected from everyone, are the places where she finds intimacy, whereas at small parties she feels invaded and threatened by the possibility of getting to know someone.

Throughout the parties, food has a special signification in Gatsby, if taken as an explicit reference to Petronius' description of Trimalchio's dinner, which is so out of proportion that it could feed an army. The descriptions of abundant exotic dishes are detailed in both narratives and seem to serve the same function of showing their attempt to be seen as important people, as verified on the following passages:

On the tray stood a donkey made of Corinthian bronze, bearing panniers containing olives, white in one, and black in the other. [...] Dormice sprinkled with poppy seeds and honey were served on little bridges soldered fast to the platter, and hot sausages on a silver gridiron, underneath of which were damson plums and pomegranate seeds (PETRONIUS, 1947, p. 84).

On buffet tables, garnished with glistening hors-d'oeuvre, spiced baked hams crowded against salads of harlequin designs and pastry pigs and turkeys bewitched to a dark gold. In the main hall a bar with a real brass rail was set up, and stocked with gins and liquours and with cordials so long forgotten that most of his female guests were too young to know one from another (FITZGERALD, 1971, p. 45-46).

The exotic dishes are greatly depicted in both film adaptations, in Copolla's screenplay and in the more recent Baz Luhrmann film from 2013. In the latter, beyond the extravagant dinners, food is an important element in other scenes. Gatsby proudly announces a dish in the scene when he takes Nick to the illegal bootleg Jazz Club. As they sit at a table, he advises him to try "the lobsters decorated with truffles and fine herbs" (Luhrmann), an odd combination of ingredients, which are commonly served separately in high-end gourmet restaurants.

In both films and narratives, despite the odd combinations of dishes served, it is the drinking, dancing and playing that are privileged. Comparatively, beyond the lavishing display at parties, both characters also share a taste for wearing extravagant objects, especially a ring on the little finger, as described it in the passage below: 
On the little finger of his left hand he wore a massive gilt ring, and on the first joint of the next finger, a smaller one which seemed to me to be of pure gold but as matter of fact it had iron stars soldered on all around it. And then, for fear all his finery would not be displayed, he bared his right arm, adorned with a golden arm-band and an ivory circlet clasped with a pate of shinning metal (PETRONIUS, 1947, p. 85).

The ring is a symbol of good taste, but also alludes to the fakeness of his character, as although it appears to be made of gold, soon it is seen for what it is made from, and that is iron.

Fitzgerald also describes Gatsby wearing a ring, what is recovered in both film adaptations, particularly in Clayton's film adaptation (1974) where in the final scene, Gatsby wears an emerald ring which is reflected in the green light at the end of Daisy's dock, while Nick says Fitzgerald original lines: "He had come a long way to this lawn. And his dream must have seemed so close, that he could hardly fail to grasp it. He did not know that it was already behind him" (p. 119).

According to Candace U. Grissom (2014, p. 52), the emerald ring is one of the most powerful symbols in the movie, as it represents fresh hope and Romanticism. It is also the symbol of a desire for success in a new paradise that drove the new settlers to America. The ring he gives to Daisy and is rejected is connected to Fitzgerald's Irish roots in the Emerald Isle as well as with his impression about America failing to level up to the ambitions of the immigrant sons.

The ring is also present in Lurhmann's adaptation in many of the scenes. When Gatsby introduces himself to Nick, we first see a ring with an engraved black stone in his little finger.

When Nick explains to Gatsby that he cannot see something that has stayed behind, he is pointing to another concern Gatsby has: time, which is another element present as a feature of Trimalchio. Amongst the strange costumes and objects, Trimalchio owns a clepsydra and a trumpeter to inform him how much time he has lost in his life. He also has a Greek astrologer that can predict how long he has to live. When he is introduced, we learn that: “Don't you know with whom your engagement is today? The exquisite Trimalchio, Who keeps a clock and a liveried bugler in his dinning- room, so that he can tell, instantly, how much of his life has run out!" (PETRONIUS, 1947, p. 79). In another passage in which he is describing the simulation of his funeral he states:

On my right you can place a statue of Fortunata holding a dove and leading a little bitch on a leash, and my favorite boy, and large jars sealed with gypsum, so the wine won't run out; show one broken and a boy crying over it. Put a Sun dial in the middle, so that whoever looks to see what time it is must read my name whether he wants or not (p. 137).

Following that perspective, according to Niall S. Slater (2011, p. 129), the word "time" occurs 87 times in The Great Gatsby. After Gatsby's death, when his father shows up for Gatsby funeral, he shows Nick a diary "Gatz" had kept as a young boy, with a schedule for work, sports and self improvement as we can read below: 
He opened it at the back cover and turned it around for me to see. On the last fly-leaf was printed the word SCHEDULE, and the date September 12, 1906. and underneath:

Rise from bed ............ . 6.00 A.M. Dumbbell exercise and wall-scaling ... ... 6.15-6.30 " Study electricity, etc ... ....... 7. 7.15-8.15 "Work ... ... . . . . . . . ... ... 8.30-4.30 P.M. Baseball and sports ... ... ... ... . 4.30-5.00" Practice elocution,

poise and how to attain it 5.00-6.00" Study needed inventions ... ... . . . . 7.009.00" GENERAL RESOLVES No wasting time at Shafters or [a name, indecipherable] No more smokeing or chewing Bath every other day Read one improving book or magazine per week Save \$5.00 \{crossed out\} \$3.00 per week Be better to parents (FITZGERALD, 1971, p. 132).

In Luhrmann's film (2013), time is brought up as a theme not only in the dialogues, but the director also pays close attention to the objects functioning as symbols. For instance, in the scene when Gatsby meets Daisy, he breaks a clock as if he wishes time to stop or not move forward. The character also wears a watch in most of the scenes, reminding us of Trimalchio's trumpeter as if his wristwatch could also tell him how much time he has lost apart from Daisy. In the movie he tells Nick that his life needs to be an ever-ending ascending trajectory as he points to a falling star in the sky. Gatsby wants no less than his metamorphosis into royalty so that he can marry royalty. We can follow Nick's objection to his belief in the next passage:

"I wouldn't ask too much of her," I ventured. "You can't repeat the past". "Can't repeat the past?" He cried incredulously. "Why of course you can!" He looked around him wildly, as if the past were lurking here in the shadow of his house, just out of reach of his hand. 'I'm going to fix everything just the way it was before,' he said, nodding determinedly. "She'll see" (FITZGERALD, 1971, p. 117).

However, as Gatsby takes Daisy on a tour around his house after their meeting, Nick observes that "the expression of bewilderment had come back into Gatsby's face, as though a faint doubt had occurred to him as to the quality of his present happiness" (p. 75). Meanwhile, he stops throwing parties, lets most of the house servants go and his house is gradually emptied until it has gained an aspect of abandonment, reflecting his current situation, so that "as obscurely as it had begun, his career as Trimalchio was over" (p. 87).

Regardless his sensing his end, he eludes himself with the idea that Daisy will become his princess, although Nick realizes that Daisy "never intended doing anything at all" (p.108). Although it becomes clear that Daisy does not care about him at all, Gatsby keeps on waiting for her call until "the holocaust was complete" (p. 128), when Nick finds his body in the pool and Wilson's body lying on the grass. Henceforth, the old order is reestablished as power is retained in the hands of old riches. Daisy and Tom just move to another city to carry on with their lives as if nothing had happened. In the end, just as Trimalchio's house is burned down by accident, Gatsby is shot dead as the result of an accident which leads to Tom plotting against him and ultimately Wilson murdering him. The difference 
is that whilst the fire at the end of Trimalchio's dinner is meant to have a hilarious effect, the deaths at the end of Gatsby have a tragic tone, unveiling the empty empire he had created for himself and the empty empires in the lives of those who carry on.

Fitzgerald was irrevocably inspired by Petronius' character Trimalchio, whose name was the title of the earlier version of the Great Gatsby. However, unlike Trimalchio, Gatsby is not only about a comical figure, who has inherited money but no manners, and gets laughed at his nonsense ideas and taste. Fitzgerald gives Gatsby an empathizing character through the more dynamic observations of Nick Carraway, who changes his perception of Gatsby as the story unfolds. From despising someone he took for another tacky new rich on account of his extravagant displays of money, Nick comes to realize Gatsby is worth much more than the whole bunch of his rich friends. Therefore, the character of a self-made man, who is also irrevocably hopeful and romantic, grows contrastingly to the exposing of pervading cynicism of his society.

Although Satyricon's narrator gives us a more static view of Roman society, Nick presents himself with the eye of an outsider who simultaneously joins the actions. In both stories, these actions are displayed in large parties and extravagant dinners, where guests from different backgrounds attend the functions at mansions full of curious objects and new inventions. These parties are attended by all sorts of people, who let their masks off while engaging in a carnivalesque function.

This essay has discussed that beyond both protagonists' obsessions with displaying their money, they can only be brought closely in analytic terms due to their preoccupation with time, and more evidently due to the symbolism embedded in the ring, whereas they remain distant in terms of their charm and romantic view.

\section{Versóes e inversóes do Satyricon de Petrônio em O Grande Gatsby}

Resumo: Haja vista o conceito de carnavalização de Bakhtin, esta análise explora comparativamente Satyricon e O Grande Gatsby, a fim de discutir relações intertextuais estabelecidas entre os protagonistas Gastby e Trimalquião, bem como relações que emergem entre as posições dos narradores de ambas as obras, Nick Carraway e Encólpio. Para tanto, o artigo também se volta para as adaptações cinematográficas da obra de Fitzgerald, dirigidas por Jack Clayton (1974), e a mais recente por Bax Luhrmann (2013).

Palavras-chave: Satyricon. O Grande Gatsby. Carnavalização.

\section{REFERENCES}

BAKHTIN, M. Problems of Dostoevsky's Poetics. Minneapolis: University of Minnesota, 1929.

BAKHTIN, M. Rabelais and His World. Bloomington: Indiana UP, 1941.

BEVILACQUA, W. F. ... and the long secret extravaganza was played out: The Great Gatsby and Carnival in a Bakhtinian Perspective. Connotations, v. 13, n. 1, 
2003/2004. Available at: <http://www.connotations.unituebingen.de/bevilacqua 01312.htm>. Accessed on: October 2, 2015.

CHURCHWEL, S. Careless People: Murder, Mayhem, and the Invention of The Great Gatsby. LCC, USA: Penguin Group, 2014.

DOULAMIS, K. Echoing Narratives: Studies of Intertextuality in Greek and Roman Prose Fiction. Groningen: Barkhuis Publishing, 2011.

FITZGERALD, S. The Great Gatsby. Harondsworth: Penguin Books, 1971.

GRISSOM, C. U. Fitzgerald and Hemingway on Film: A Critical Study of the Adaptations, 1924-2013. Jefferson, NC: McFarland, 2014.

KÖNIG, J.; WHITMARSH, T. Ordering Knowledge in the Roman Empire. Jason König, Tim Whitmarsh (ed.). New York: Cambridge UP, 2007.

PETRONIUS, A. The Satyricon of Petronius Arbiter. Translation W. C. Firebaugh. New York: Liveright Publishing, 1943.

SLATER, N. W. His Career as Trimalchio: Petronian Character and Narrative in Fitzgerald's Great American Novel. Fictional Traces: Receptions of the Ancient Novel, v. 2, Pinheiro Marilia. Futre and Harrison, Sthephen J. (ed.). Groningen: Burhuis P. and Groningen Un. Library, 2011. p. 125-133.

THE GREAT Gatsby. Dir. Baz Lurhmann, Warner Bros, 2013.

THE GREAT Gatsby. Dir. Jack Clayton, Newdon Productions and Paramount Pictures, 1974.

Recebido em agosto de 2016.

Aprovado em junho de 2017. 